\title{
16
}

\section{Public Communication on Nuclear Deterrence and Disarmament: The Challenge for Australia}

\author{
Tanya Ogilvie-White
}

'Foreign policy doesn't lend itself to clear storytelling. Much of its work is elusive and incremental and happens behind closed doors and over time. It's the work of persuasion.' ${ }^{\prime}$ These are the words of Allan Gyngell, president of the Australian Institute of International Affairs and author of Fear of Abandonment: Australia in the World Since 1942. As someone who has spent most of his life behind the closed doors to which he refers, and who is now responsible for drawing the Australian public into debate on foreign and defence issues, he knows better than most the communication challenges that governments face. When it comes to engaging the public on the US alliance, and its nuclear dimension in particular, these challenges are complex and growing. This chapter explores these challenges, some of which are unique to Australia. It argues that Canberra's decision-makers have reached a critical juncture in their attempts to reconcile Australian approaches to nuclear deterrence and disarmament: policies that have been problematic for years are threatening to backfire, the result of declining legitimacy, domestic political missteps and events that are beyond Canberra's control.

1 Allan Gyngell, 'Australian Foreign Policy: Does the Public Matter? Should the Community Care?', Australian Outlook, 7 December 2017, www.internationalaffairs.org.au/australianoutlook/ foreign-policy-should-community-care/. 
It then sets out a proposal for Australian decision-makers to consider, which would help narrow the gaps between Australias nuclear deterrence and disarmament policies and public opinion.

\section{The Treaty on the Prohibition of Nuclear Weapons and Extended Deterrence}

In Australia, as in other countries that rely on US extended deterrence for their security, government policies on nuclear deterrence and disarmament are facing a growing legitimacy problem. This is not new, but it has become more difficult to manage since the adoption and entry into force of the Treaty on the Prohibition of Nuclear Weapons (TPNW), which has significantly advanced a global norm against nuclear weapons possession and reliance. Conscious of the new treaty's challenge to the legitimacy of nuclear deterrence doctrines, including nuclear assurance, the Australian Government attempted to derail TPNW negotiations and, having failed to do so, strongly and consistently denounces the new treaty, despite widespread support for it among the Australian public. ${ }^{2}$ This raises serious questions about the credibility and legitimacy of Canberra's longstanding approach to reconciling nuclear deterrence and disarmament-that is, quietly relying on extended deterrence while focusing domestic attention on nuclear disarmament as a long-term goal. Decades of intense secrecy and exceptionally narrow and restricted public engagement on nuclear issues could now backfire, as Australia's decision-making elite try to sell the strengths of its nuclear arrangements to a wary public.

2 Although none of Australia's leading think tanks has published polls on Australian attitudes to the TPNW, data are available from other sources. In September 2017, a ReachTel survey of 1,669 Australian residents found 73 per cent of Australians want the government to sign the TPNW and 11 per cent oppose it. It also found 77 per cent of respondents think nuclear weapons make the world less safe and more than half of those surveyed said they would be more likely to vote for a party that supports a ban on nuclear weapons. In 2018, an Ipsos public opinion poll found 78.9 per cent of Australian respondents supported Australia joining the TPNW and only 7.2 per cent opposed, with 10.1 per cent undecided. In 2019, the ICRC's 'Millennials on War' survey of 16,000 young adults in 16 countries, including Australia, found millennials overwhelmingly supported nuclear disarmament and opposed the use of nuclear weapons ( 80 per cent), but found most of the people they surveyed had not heard of the TPNW. See Greenpeace Australia Pacific, 'Poll on Australians' Attitudes to Nuclear Weapons', 19 September 2017, www.greenpeace.org.au/blog/poll-australians-attitudes-towardsnuclear-weapons/; Ipsos Public Opinion Poll, cited in International Human Rights Commission, 'Australia and the Treaty on the Prohibition of Nuclear Weapons', December 2018, hrp.law.harvard. edu/wp-content/uploads/2018/12/Australia-TPNW-12-12-18-FINAL.pdf; ICRC, Millennials on War, 25 November 2019, www.icrc.org/sites/default/files/wysiwyg/campaign/millennials-on-war/icrcmillennials-on-war_full-report.pdf. 
Adoption of the TPNW has coincided with several developments that are beyond Canberra's control, but which increase Canberra's communication challenges: the collapse of nuclear arms control agreements and resurgence of nuclear tensions among the great powers; a rise in the salience of nuclear weapons in US-China relations; a renewed focus on nuclear deterrence in the US alliance; and declining confidence in any nuclear-armed state's capacity to prevent nuclear catastrophe, especially in the context of escalatory pressures and new technologies that could undermine command and control. ${ }^{3}$ These developments make deterrence and disarmament even harder to reconcile, exposing the extreme fragility of Australia's policy balance. It is becoming harder to deny that Australia's position within the US alliance and reliance on extended deterrence place Canberra in the role of nuclear enabler and disarmament laggard, regardless of whether it actively contributes to nuclear risks or supports the ongoing shift towards increased nuclear salience.

\section{Disarmament, Deterrence and Public Persuasion}

Amid these developments, nuclear disarmament advocates have a distinct public communication advantage over government, despite the former's limited resources. This is partly because vivid stories about the risks of catastrophic nuclear war are more compelling than abstract discussion about the role of nuclear deterrence in promoting strategic stability. Equally significant is the fact that pro-disarmament, pro-TPNW storytellers can more easily claim the moral high ground than their pro-deterrence counterparts, even though some of the ethical questions surrounding nuclear deterrence

3 Joseph D. Becker, 'Strategy in the New Era of Tactical Nuclear Weapons', Strategic Studies Quarterly 14(1), 2020, 117-40, www.airuniversity.af.edu/Portals/10/SSQ/documents/Volume-14_ Issue-1/Becker.pdf; John Borrie, Strategic Technologies, Nuclear Risk Reduction Policy Brief No. 2 (Geneva: UNIDIR, 2020), doi.org/10.37559/WMD/20/NRR/03; Erik Gartzke and Jon R. Lindsay, eds, Cross-Domain Deterrence: Strategy in an Era of Complexity (Oxford: Oxford University Press, 2019), doi.org/10.1093/oso/9780190908645.001.0001; James Johnson, 'Deterrence in the Age of Artificial Intelligence and Autonomy: A Paradigm Shift in Nuclear Deterrence Theory and Practice?', Defence and Security Analysis 36(4), 2020, 422-48, doi.org/10.1080/14751798.2020.1857911; Brad Roberts, 'On Adapting Nuclear Deterrence to Reduce Nuclear Risk', Daedalus 149(2), 2020, 69-83, doi.org/10.1162/daed_a_01790.

4 Moreover, the risks of a disarmed world are speculative, while the failure modes and risks of nuclear deterrence 'stand out sharply from past crises and behaviour'. Lewis A. Dunn, Some Reflections on UNIDIR's Disarmament, Deterrence, and Strategic Arms Control Dialogue - Looking Ahead (Geneva: UNIDIR, 14 January 2021). 
and disarmament are far from black and white. ${ }^{5}$ Disarmament advocacy groups in Australia and overseas are aware of this phenomenon, which has helped them rally public support behind the TPNW and mobilise a younger demographic of potential disarmament activists. Indeed, a recent survey by the International Committee of the Red Cross (ICRC) (which has driven much of the global debate on the humanitarian consequences of nuclear weapons), has highlighted the strengths of communication strategies that frame disarmament advocacy around the use of nuclear weapons rather than their possession. Based on the views of 16,000 young adults aged from 20 to 35 in 16 countries, including Australia, the ICRC's 'Millennials on War' survey found that millennials are overwhelmingly opposed to the use of nuclear weapons, with more than eight out of 10 respondents believing that it is 'never acceptable'.

The ICRC's recent findings are significant for those trying to manage public communication on nuclear deterrence and disarmament. The approach of Australia's Liberal-National Coalition (in government since 2013) has been to criticise the TPNW on the basis that it 'has not engaged any state that possesses nuclear weapons', 'will not eliminate a single nuclear weapon .... ignores the realities of the global security environment ... has weaker safeguards provisions than the existing NPT framework' and is 'inconsistent with [Australia's] US alliance obligations'. ${ }^{7}$ None of these arguments directly addresses public concerns about the risks and consequences of nuclear use, and thus does not lend itself to persuasive messaging let alone compelling storytelling. Instead, such arguments echo US denouncements of the treaty, which are unlikely to be persuasive to the Australian non-expert.

Recent studies exploring opinion on nuclear disarmament and deterrence among other US allies and partners reveal that these communication challenges are not unique to Australia. ${ }^{8}$ A recent survey conducted

5 Tanya Ogilvie-White, The Logic of Nuclear Deterrence: Assessments, Assumptions, Uncertainties and Failure Modes (Geneva: UNIDIR, 25 November 2020), doi.org/10.37559/WMD/20/DDAC/03.

6 Magnus Lovold, 'Lessons from the ICRC's Millennials on War Survey for Communication and Advocacy on Nuclear Weapons', Journal for Peace and Nuclear Disarmament 4(2), 2020, 410-17. doi. org/10.1080/25751654.2020.1859216.

7 Department of Foreign Affairs and Trade, 'Nuclear Issues', 20 September 2021, www.dfat.gov. $\mathrm{au} /$ international-relations/security/non-proliferation-disarmament-arms-control/nuclear-issues/ treaties\#tpnw.

8 See, for example: Manuel Lafont Rapnouil, Tara Varma and Nick Witney, 'Eyes Tight Shut: European Attitudes to Nuclear Deterrence', European Council on Foreign Relations, 19 December 2018, ecfr.eu/special/eyes_tight_shut_european_attitudes_towards_nuclear_deterrence/. 
in Japan is particularly illuminating, providing insight into Japanese attitudes to the TPNW and the extent to which those attitudes can be influenced. ' First, pollsters asked respondents from a cross-section of Japanese society $(\mathrm{N}=1333)$ whether they wanted their prime minister to sign, and Diet to ratify, the TPNW. The results of this initial survey question mirrored the November 2018 Ipsos poll on Australian attitudes, with 75 per cent of Japanese respondents supporting joining the TPNW, 17.7 per cent opposing it and 7.3 per cent undecided. Having gauged a baseline of support, respondents were then shown three real-world criticisms of the treaty to test whether they could be persuaded to change their opinion, based on: 1) claims the treaty would undermine the nuclear umbrella that protects Japan's security, 2) a warning that the treaty is weak because it lacks verification mechanisms and 3) assertions that the TPNW undermines the Treaty on the Non-Proliferation of Nuclear Weapons (NPT). They were also tested to see whether their TPNW support could be weakened in response to peer pressure. Interestingly, respondents' attitudes did not shift significantly in response to any of the criticisms or in response to peer pressure. These findings provided a striking contrast to those from a parallel US study, which found American public support for the treaty declined in response to each argument, and especially security-centric criticisms. No studies of this kind have been conducted in Australia, but the robustness of the Australian public's views on the TPNW may well be closer to Japan's, having developed its own version of the Japanese 'nuclear allergy'. ${ }^{10}$

\section{Australia's Vague Nuclear Assurances}

Some of the difficulties of reconciling deterrence and disarmament in public communication strategies are particular to Australia. Whereas other US allies can balance public support for nuclear disarmament against a formal pledge of US nuclear assurances, Australia cannot. This weakens Canberra's security arguments in support of nuclear extended deterrence

9 Jonathan Baron, Rebecca Davis Gibbons and Stephen Herzog, 'Japanese Public Opinion, Political Persuasion, and the Treaty on the Prohibition of Nuclear Weapons', Journal of Peace and Nuclear Disarmament 3(2), 2020, 299-309, doi.org/10.1080/25751654.2020.1834961.

10 Tanya Ogilvie-White, 'Australia's Rocky Nuclear Past and Uncertain Future', Bulletin of the Atomic Scientists, 1 September 2015, doi.org/10.1177\%2F0096340215599783; Parliament of Victoria, Inquiry into Nuclear Prohibition, November 2020, www.parliament.vic.gov.au/images/stories/committees/ SCEP/Inquiry_into_Nuclear_Prohibition_Inquiry_/Report/LCEPC_59-03_Inquiry_into_Nuclear_ prohibition.pdf. 
and against the TPNW. Having never received an explicit, public promise of nuclear assurance from Washington, despite stating its own expectations in successive white papers since 1994, Australia now finds itself in a position whereby it is becoming a more credible nuclear target (partly due to its joint facilities and their role in US targeting), with only the vaguest of commitment from the US to intervene on Canberra's behalf should the need arise. Putting aside the point that even a formal nuclear pledge would not guarantee US assistance, from the perspective of public communication, this situation poses a serious problem. A communication strategy that presents nuclear weapons as security providers (and the TPNW as a threat to that security) lacks credibility if it cannot be backed up with evidence of a firm commitment — and even more so in the face of Australia's increasing exposure to nuclear risks. This point has not been lost on Australia's expert community, which has become more vocal in its criticisms of official policy, with some calling for more robust nuclear assurances ${ }^{11}$ others arguing that it is time for Australia to revisit developing an independent nuclear capability ${ }^{12}$ and still others pushing for the abandonment of nuclear deterrence altogether. ${ }^{13}$

These developments help explain why Canberra's decades-old bipartisan consensus on deterrence and disarmament is coming to an end, raising the stakes in future public communication efforts. ${ }^{14}$ As the issue becomes more politicised, the legitimacy issue will come increasingly to the fore. The TPNW and the question of US extended deterrence could well become a major election issue, which could prove highly divisive and, depending on how it is managed, strategically risky. For example,

11 Fiona S. Cunningham, 'Managing US-China Nuclear Risks: A Guide for Australia', United States Studies Centre, 29 September 2020, www.ussc.edu.au/analysis/managing-us-china-nuclear-risks-aguide-for-australia; Stephen Frühling, Andrew O'Neil and David Santoro, 'Escalating Cooperation: Nuclear Deterrence and the US-Australia Alliance', United States Studies Centre Deterrence Brief, November 2019, www.ussc.edu.au/analysis/escalating-cooperation-nuclear-deterrence-and-the-usaustralia-alliance; Ashley Townshend and Brendan Thomas-Noone with Matilda Steward, 'Averting Crisis: American Strategy, Military Spending and Collective Defence in the Indo-Pacific', United States Studies Centre, August 2019, www.ussc.edu.au/analysis/averting-crisis-american-strategymilitary-spending-and-collective-defence-in-the-indo-pacific.

12 Sam Roggeveen, 'Maintaining Australia's Security as American Power Recedes', Lowy Institute, interactives.lowyinstitute.org/features/covid-recovery/issues/security/.

13 Marianne Hanson, 'Where Will Australia Stand on Banning Weapons of Mass Destruction?', The Interpreter, 27 October 2020, www.lowyinstitute.org/the-interpreter/where-will-australia-standbanning-weapons-mass-destruction.

14 Anthony Albanese (leader of the Australian Labor Party), 'Moving Support for the Nuclear Weapon Ban Treaty', Speech to the 48th National Conference of the Australian Labor Party, Adelaide Convention Centre, 18 December 2018, anthonyalbanese.com.au/speech-moving-support-for-thenuclear-weapon-ban-treaty-tuesday-18-december-2018. 
a government determined to retain a role for nuclear weapons in Australia's security architecture, through the US alliance or other arrangements, might attempt to justify the Australian public's exposure to increased nuclear risk by exaggerating threats and mobilising public opinion against adversaries. ${ }^{15}$ Although this might be seen by some as a tempting election tactic, it could inflame and empower nationalist and xenophobic sentiment - a dangerous game, especially in the age of social media and fake news. Equally, once in government, a political leader who campaigned on a pro-TPNW platform could find themselves under public pressure to follow through on disarmament commitments that could undermine the US alliance, with implications for conventional deterrence. ${ }^{16}$ Although this would not be an inevitable outcome of Australia signing and ratifying the TPNW, military dependence on the alliance (combined with Washington's willingness to punish allies that step out of line) makes it a credible scenario that should not be dismissed. ${ }^{17}$

\section{Reframing the Discussion}

The above scenarios highlight the importance of managing Australia's deterrence and disarmament dilemma in a way that rebuilds political consensus and that brings the public along. The past decade has seen some serious missteps in this regard, as successive governments, often under intense US diplomatic pressure, have tried and failed to reconcile diverging deterrence and disarmament goals. To be fair, every road ahead is strewn with political and strategic risk. With no obvious

15 Australian political leaders are not immune to this temptation. In launching the 2020 Defence Strategic Update, Prime Minister Scott Morrison drew parallels between the current strategic environment in the Asia-Pacific and 'similar times many years ago in the 1930s'. Prime Minister of Australia, 'Address-Launch of the 2020 Defence Strategic Update', 1 July 2020, www.pm.gov.au/ media/address-launch-2020-defence-strategic-update.

16 This is a possibility if the TPNW becomes a major election issue in Australia. The leadership of the Labor Party is currently divided on the merits of Australia signing the TPNW (some key figures oppose it and even the Labor leader's support for it appears to be carefully qualified). If, however, the party decides a disarmament platform could be part of a successful election strategy, it might unite behind the TPNW and find itself with a mandate to radically overhaul Australia's defence and security policy. 17 For two perspectives, see Tanya Ogilvie-White, 'Australia and Extended Nuclear Assurance', in Perspectives on Nuclear Deterrence in the 21st Century, ed. Beyza Unal, Yasmin Afina and Patricia Lewis (London: Chatham House, 2020), www.chathamhouse.org/sites/default/files/2020-04-20-nucleardeterrence-unal-et-al.pdf; International Human Rights Commission, 'Australia and the Treaty on the Prohibition of Nuclear Weapons'; Richard Tanter, 'An Australian Pathway through Pine Gap to the Nuclear Ban Treaty', Pearls and Irritations, 5 August 2019, johnmenadue.com/richard-tanter-anaustralian-pathway-through-pine-gap-to-the-nuclear-ban-treaty/. 
alternative, Australia's approach has been to try to maintain the status quo. But growing awareness of the potential for deterrence breakdown and escalation, combined with Australian public support for the TPNW and the collapse of the bipartisan consensus, means a new approach is needed. As others have argued, leaders cannot hide from the TPNW, however hard they try. ${ }^{18}$

Australia needs to address this problem in a way that allows it to preserve the US alliance, acknowledge escalatory risks and demonstrate constructive leadership on nuclear disarmament. To do this, it needs to reframe the debate. The first step is to acknowledge that the TPNW is an important part of the longer-term goal of nuclear elimination-a significant international achievement that, over time and if fleshed out sufficiently, has the potential to help create a more secure world. There is nothing to be gained by continuing with a policy of TPNW-bashing, which is jarring for so many and, in any case, undermines international law now that the TPNW has entered into force. Instead, the Australian Government could explain its holdout status as a temporary position, to be reassessed if the treaty is strengthened and strategic circumstances change. This position, expressed in positive and forward-looking language, but without making a formal pledge, has more authenticity and legitimacy than the current policy, and while it will require careful handling within the alliance context, more closely aligns with Australian values.

The second step is to address the subject of nuclear deterrence with more openness in national conversations, policy documents and strategic dialogues-a significant departure from the closed-door policy that Australia has maintained over so many years. This would need to include discussion of what Australia is doing to reduce nuclear risks, including its efforts to prevent nuclear war. Indications are that the Australian public would be open to this discussion, given that those who support the TPNW do so because they do not believe the use of nuclear weapons can be justified under any circumstances (in common with publics in other alliance states, Australians are willing to accept nuclear possession, but

18 Baron et al., 'Japanese Public Opinion', 305; George Perkovich, 'Living with the Nuclear Prohibition Treaty: First, Do No Harm', CEIP Commentary, 10 November 2020, carnegieendowment. org/2020/11/10/living-with-nuclear-prohibition-treaty-first-do-no-harm-pub-83198. 
not use) ${ }^{19}$ Effective communication could generate support for a strategy of continuing to hold out from the TPNW for now, while other, more immediate nuclear risk-reduction and disarmament measures are pursued.

The success of the second step is dependent on Australia showing genuine leadership on nuclear risk reduction and disarmament and using its influence within the US alliance to that end. This calls for a bold initiative. One idea is to kickstart discussions on a no-first-use (NFU) treaty-a formal, negotiated commitment by all nuclear-armed states not to be the first to use nuclear weapons - or a broader NFU dialogue, which includes some of the most destabilising non-nuclear weapons in the discussion. This has several advantages in the current strategic climate:

1. It would reduce the chance of a surprise nuclear attack by encouraging states that have NFU doctrines to maintain them, and those that do not to commit to them as a confidence-building measure.

2. It would be strongly supported by the Australian public (and publics in other alliance states), which supports nuclear possession but not use.

3. It would help Australia demonstrate its commitment to the NPT, which calls for a reduction in the salience of nuclear weapons in strategic doctrines.

4. It would find support among like-minded states (including members of the Stockholm Initiative), which could be leveraged to advance an NFU proposal in the UN First Committee or other diplomatic fora.

5. It has a reasonable chance of being taken seriously by the Biden administration, which has assembled a strong arms control team and is likely to prioritise nuclear risk reduction. ${ }^{20}$

6. It would coincide with the launch of a global NFU campaign, led by influential non-governmental organisations and civil society groups in Europe and the Asia-Pacific.

19 Lovold, 'Lessons from the ICRC's Millennials on War Survey'.

20 The stage has already been set for this debate in the US. In January 2019, Senator Warren and Representative Smith introduced the No First Use Act, which states: 'It is the policy of the United States to not use nuclear weapons first'. 
There are many criticisms that can be levelled against NFU doctrines, ${ }^{21}$ including strategic arguments over the credibility of nuclear threats, which some deterrers argue rely on an adversary signalling its ability and willingness to strike first (to the extent that some believe nuclear weapons should be kept ready for prompt launch, as is the case with US and Russian arsenals). ${ }^{22}$ But other strategic thinkers question these assumptions, based on uncertainties stemming from a combination of aggressive doctrines and postures, and uncertainties surrounding new technologies and domains of warfare, all of which are heightening threat perceptions and increasing the risks of escalation and nuclear use. ${ }^{23}$ NFU commitments would not eliminate these risks, but they could help reduce them, especially if they are adopted as part of a wider package of confidence-building measures. Further, actively championing NFU commitments at the international level would be an example of ambitious and principled disarmament diplomacy_-something Australia was respected for in the past and could be known for again.

21 William A. Chambers, Caroline R. Milne, Rhiannon T. Hutton and Heather W. Williams, No-First Use of Nuclear Weapons: A Policy Assessment, IDA Paper P-20513, January 2021, www.ida.org/-I media/feature/publications/n/no/no-first-use-of-nuclear-weapons-a-policy-assessment/p-20513.ashx.

22 The strategic objections against NFU and sole purpose do have some validity in the context of the US alliance, but they could be overcome if the US demonstrated to allies that it was significantly improving its conventional capabilities and strengthening alliance cohesion, resilience and defence and security cooperation. See George Perkovich and Pranay Vaddi, Proportionate Deterrence: A Model Nuclear Posture Review (Washington: CEIP, 2021), carnegieendowment.org/files/Perkovich_Vaddi_NPR_full.pdf.

23 See, for example: Steve Fetter and John Wolfsthal, 'No First Use and Credible Deterrence', Journal for Peace and Nuclear Disarmament 1(1), 2018, 102-14, doi.org/10.1080/25751654.2018.1454257; John P. Holdren, 'The Overwhelming Case for No First Use', Bulletin of the Atomic Scientists 76(1), 2020, 3-7, doi.org/10.1080/00963402.2019.1701277; Johnson, 'Deterrence in the Age of Artificial Intelligence'. 
This text is taken from Alliances, Nuclear Weapons and Escalation: Managing Deterrence in the 21st Century, edited by Stephan Frühling and Andrew O'Neil, published 2021 by ANU Press, The Australian National University, Canberra, Australia.

doi.org/10.22459/ANWE.2021.16 